\title{
Oxidation of lithospheric mantle beneath Tanzania by melt reaction
}

\author{
Shao-Bing Zhang ${ }^{1}$, Roberta Rudnick ${ }^{2}$, Catherine McCammon ${ }^{3}$ \\ 1 CAS Key Laboratory of Crust-Mantle Materials and Environments, School of Earth and Space Sciences, \\ University of Science and Technology of China, Hefei 230026, China \\ 2 Department of Earth Science, University of California at Santa Barbara, Santa Barbara, CA 93106-9630, \\ USA \\ 3 Bayerisches Geoinstitut, Universität Bayreuth, D-95440 Bayreuth, Germany
}

\section{Introduction}

The oxidation state of the mantle is a key parameter in controlling the speciation of fluids and melt and can influence the mantle solidus and resulting melt properties. The variation of mantle oygen fugacity has important influence on magma genesis, magmga degassing, mantle metasomatic processes and the production of diamonds.

The existing data shows that most of the spinel peridotites at the top of the upper mantle yield oxygen fugacity within \pm 2 log units relative FMQ buffer. The garnet peridotites from cratonic lithosphere reveal a general decrease in fo2 with depth, which appears to result from the effect of pressure on the controlling Fe3+/Fe2+ equilibria. This has been confirmed by a series of studies (e.g., McCammon and Kopylova, 2004; Lazarov et al., 2009; Stagno et al., 2013). On the other hand, the oxidation state of cratonic mantle is readily to be modified by fluid infiltration and melt reaction (e.g., Creighton et al., 2009; 2010). Both geophysical and geochemical evidence shows that the base of the Tazania Craton has been modified by mantle plume. To understand how the oxygen fugacity of cratonic mantle has been affected by mantle plumes, we collected some garnet and spinel peridotites from the Tanzania Craton to study their oxidation state. The peridotite xenoliths were collected from the Labait volcano, which lies on the border between the Archean Tanzanian Craton and the Neoproterozoic Mozambique Belt.

\section{Mineral chemistry and P-T calibration}

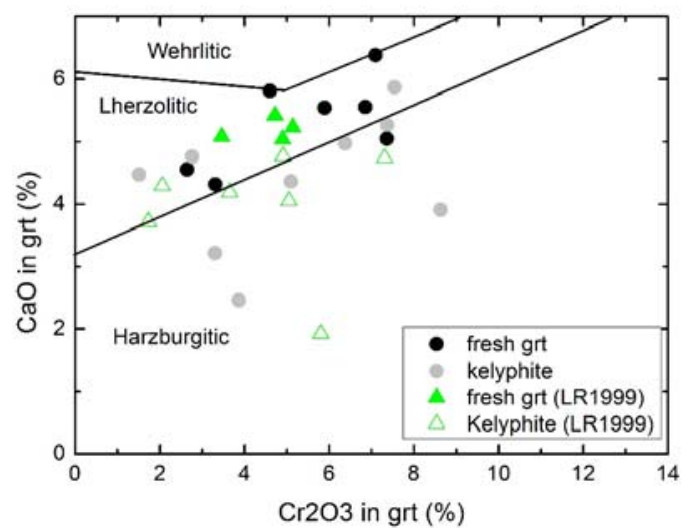

Fig. $1 \mathrm{CaO}$ versus $\mathrm{Cr}_{2} \mathrm{O}_{3}$ in fresh garnet and kelyphite of peridotites from Labait, Tazania.

There are both lhzerlite and harzburgite in the collected xenolith peridotites. Many peridotites preserve the evidence of melt reaction or fluid infiltration: coarsening of clinopyroxene, reaction rims around clinopyroxene, veins with spinel or phologpite, small patches enriched in clinopyroxene, phologpite and/or rutile. Among the xenoliths, seven contain fresh garnet and another four contain kelyphite or completedly decomposed garnet. Most of the fresh garnet grains are homogeneous in composition. Some garnet is replaced by kelyphite, fine-grained symplectic corona consists of spinel and orthopyroxene. The kelyphite rims around the fresh garnet has identical compositions with the fresh garnet except a few kelyphites have higher $\mathrm{MgO}$ and $\mathrm{Cr}_{2} \mathrm{O}_{3}$ but lower $\mathrm{CaO}$. All the fresh garnet have 
high $\mathrm{CaO}$ contents of 4.32-6.39 and high $\mathrm{Cr}_{2} \mathrm{O}_{3}$ contents of 2.64-7.36. They mainly fall into the lherzolitic garnet area (Fig. 1) although most of the host periodite are actually harzburgite. The Mg\# of fresh garnet range from 83.1 to 87.0. The Fo number of olivines from the garnet-bearing peridotites range from 89.2 to 92.0. The $\mathrm{Mg}$ numbers of orthopyroxene and clinopyroxene from the garnet-bearing peridotites are 89.9-92.4 and 88.5-91.4, respectively. Some olivines have rims with lower Mg\# than the cores and adjacent orthopyroxene.

The six spinel-bearing peridotites have generally heterogenous spinel with Cr\# ranging from 46.8 to 90.1. The orthopyroxenes in the spinel peridotites have lower $\mathrm{CaO}$ and $\mathrm{Al}_{2} \mathrm{O}_{3}$ than those in the garnet peridotites. The Mg numbers of orthopyroxene and clinopyroxene from the spinel peridotites are 90.893.3 and 90.4-93.2, respectively.The Fo number of olivines from the spinel peridotites range from 90.4 to 92.7 .

The 11 garnet peridotites have equililbration temperatures of $1270-1400{ }^{\circ} \mathrm{C}$ and pressures of $4.1-5.8$ GPa according to the barometer and thermometer of Brey and Kohler (1990). Most of the P-T data are similar with previous results of Lee and Rudnick (1999) except two samples with significantly higher pressure at $5.8 \mathrm{GPa}$ (Fig. 2). They form an adiabatic decompossing trend. The 9 spinel peridotites gave Ca-in-opx temperatures (Brey and Kohler, 1990) of 930-1170 ${ }^{\circ} \mathrm{C}$ assuming a pressure of 4.5 GPa.

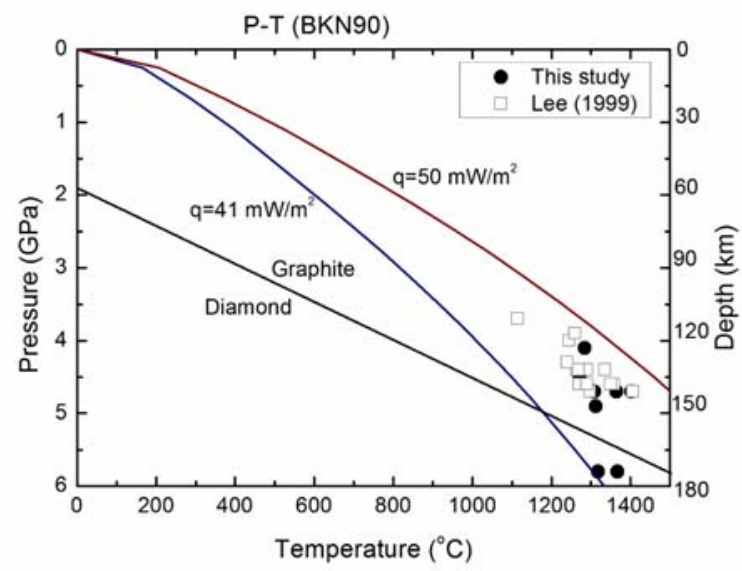

Fig. 2 Pressure and temperature estimates of Labait garnet-bearing peridotites calcualated from barometer and thermometer of Brey and Kohler (1990). The results of Lee and Rudnick (1999) are also shown for comparison.

\section{Garnet and spinel $\mathrm{fO}_{2}$}

Nine fresh garnets (six from this study and three from Lee and Rudnick, 1999) were analyzed by Mössbauer spectroscopy, yielding $\mathrm{Fe}^{3+} /$ total Fe of $0.08 \pm 0.02$ to $0.16 \pm 0.02$. The corresponding oxygen fugacity range is $-2.1 \pm 0.5$ to $-0.2 \pm 0.2$ relative to the FMQ buffer, using the calibration of Stagno et al. (2013). Five spinels/chromites (one from this study and four from Lee and Rudnick, 1999) gave $\mathrm{Fe}^{3+} /$ total Fe values of $0.32 \pm 0.04$ to $0.9 \pm 0.04$. The $\mathrm{fO}_{2} \mathrm{~S}$ obtained from these spinels are -1.8 to -0.2 relative to the FMQ buffer according O'Neill and Wall (1987), or - 0.5 to 0.4 relative to the FMQ buffer according to the calibration of Ballhaus et al. (1991). Generally, the spinel peridotites have oxygen fugacities that are consistent with those from the garnet peridotites. As shown in Fig. 3, these data show that the mantle lithosphere of the Tanzania craton is significantly more oxidized than that of the Kaapvaal craton and the Siberian craton at similar pressure (Stagno et al. 2013 and references therein). However, the Labait samples have similar oxygen fugacity to those of metasomatised xenoliths from the Slave craton (Creighton et al. 2010).

\section{Garnet trace elements}

LA-ICPMS trace element analyses on the garnets show variable REE patterns. Some are characterized by depletion in LREE, slow enrichment from MREE to HREE, which is similar to normal garnet REE patterns equilibrated with melt. Some garnets are depleted in LREE and flat from Sm to Lu. Some 
garnets have sinusoidal or humped sinusoidal REE patterns with humps at Nd, Sm or Eu, following by a decreasing in MREE with or without a concurv up in $\mathrm{Yb}$ and $\mathrm{Lu}$. This can be interpreted by reaction of peridotites with melt with different compositions, or in different degrees (Stachel et al., 2004; le Roex and Class, 2016). We hypothesize that the oxidation of the Labait peridotites may result from melt reaction, where the melt is likely derived from the plume of the East African Rift. Although the cratonic mantle has not (yet) been destroyed by the mantle plume, the oxidation state of the entire lithospheric mantle beneath the Tanzania craton may have been reset by the plume-derived magmatism.

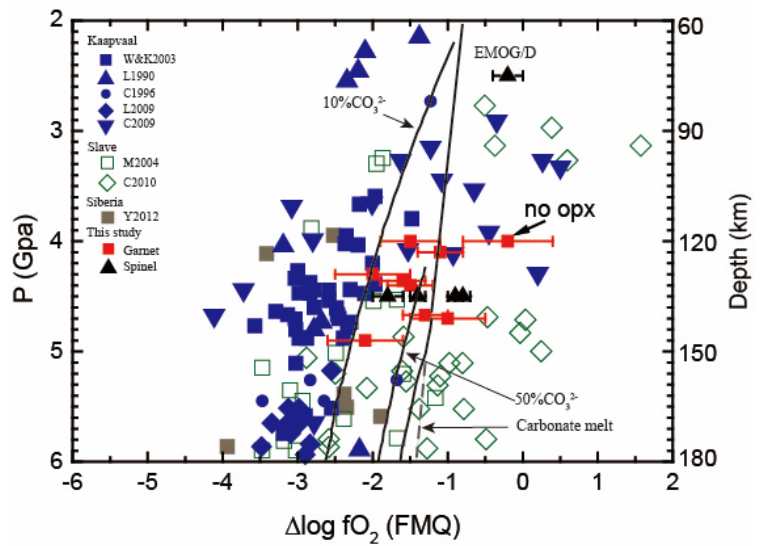

Fig. $3 \mathrm{Log}\left(\mathrm{f}_{\mathrm{O} 2}\right)$ (relative to the FMQ buffer) calculated for garnet-bearing and spinel-bearing peridotites from Labait according to the calibration of Stagno et al. (2013). The results from Kaapvaal, Slave and Siberia are shown for comparison.

\section{References}

Ballhaus C, Berry RF, Green DH (1991) High pressure experimental calibration of the olivineorthopyroxene-spinel oxygen geobarometer: implications for the oxidation state of the upper mantle. Contrib Mineral Petrol 107(1):27-40

BREY GP, KÖHLER T (1990) Geothermobarometry in Four-phase Lherzolites II. New Thermobarometers, and Practical Assessment of Existing Thermobarometers. J Petrol 31(6):13531378

Creighton S, Stachel T, Eichenberg D, Luth RW (2010) Oxidation state of the lithospheric mantle beneath Diavik diamond mine, central Slave craton, NWT, Canada. Contrib Mineral Petrol 159(5):645-657

Creighton S, Stachel T, Matveev S, Höfer H, McCammon C, Luth R (2009) Oxidation of the Kaapvaal lithospheric mantle driven by metasomatism. Contrib Mineral Petrol 157(4):491-504

Frost DJ, McCammon CA (2008) The Redox State of Earth's Mantle. Annu Rev Earth Planet Sci 36(1):389-420

Lazarov M, Woodland AB, Brey GP (2009) Thermal state and redox conditions of the Kaapvaal mantle: A study of xenoliths from the Finsch mine, South Africa. Lithos 112, Supplement 2(0):913-923

le Roex A, Class C (2016) Metasomatic enrichment of Proterozoic mantle south of the Kaapvaal Craton, South Africa: origin of sinusoidal REE patterns in clinopyroxene and garnet. Contrib Mineral Petrol 171(2):14

Lee C, Rudnick R (1999) Compositionally stratified cratonic lithosphere: petrology and geochemistry of peridotite xenoliths from the Labait tuff cone, Tanzania. In: Proceedings of the 7th international Kimberlite conference, vol., pp 503-521

McCammon C, Kopylova MG (2004) A redox profile of the Slave mantle and oxygen fugacity control in the cratonic mantle. Contrib Mineral Petrol 148(1):55-68

O'Neil HSC, Wall VJ (1987) The Olivine-Orthopyroxene-Spinel Oxygen Geobarometer, the Nickel Precipitation Curve, and the Oxygen Fugacity of the Earth's Upper Mantle. J Petrol 28:1169-1191

Stachel T, Aulbach S, Brey GP, Harris JW, Leost I, Tappert R, Viljoen KS (2004) The trace element composition of silicate inclusions in diamonds: a review. Lithos 77(1-4):1-19

Stagno V, Ojwang DO, McCammon CA, Frost DJ (2013) The oxidation state of the mantle and the extraction of carbon from Earth/'s interior. Nature 493(7430):84-88 